\title{
Leo Schnug: Alcoholic Dementia as an Unexpected Source of Inspiration for an Artist
}

\author{
François Sellal \\ Neurology Department, Hôpitaux Civils, Colmar, and INSERM U-692, Faculté de Médecine, Université de \\ Strasbourg, Strasbourg, France
}

\section{Key Words}

Alcoholic dementia $\cdot$ Cognition $\cdot$ Creativity .

Hallucinations $\cdot$ Leo Schnug

\begin{abstract}
Artistic creativity can be defined as the ability to challenge established academic representations or tastes, and to produce both innovative and esthetic works. Here, we investigate the influence of alcoholic dementia on creativity by describing the case of the famous painter Leo Schnug. It is clear that Schnug's motor and psychic disorders had a dramatic influence on his late artistic output. His hallucinations, panic attacks and delusions had an influence on both the themes and the personal, expressionistic and easily recognizable style of his work. It is unlikely that he would have attained these had he been in good health.
\end{abstract}

Copyright $\odot 2011$ S. Karger AG, Basel

Artistic creativity can be defined as the ability to challenge established academic representations or tastes, and to produce both innovative and esthetic works of art.

Though most neurological diseases result in a loss of instrumental functions, it has occasionally, though rarely, been shown that they might release or enhance artistic creativity $[1,2]$. More frequently, established artists have shown a dramatic change in their output following a stroke or a neurodegenerative disease [e.g. 3-5], giving a new style to their production. This paper describes the case of Leo Schnug, who developed documented alcoholic dementia. The works of art produced during his progressive decline betray his efforts to compensate for the deterioration in his drawing skills, but in return his psychic disorders opened artistic themes that he had yet to explore.

Leo Schnug is a painter who was born near Strasbourg in 1878 , at a time when this currently French city belonged to the German Empire. He frequented the local Decorative Arts School and then the Art School Academy in Munich, before settling in Strasbourg in 1900. Very early he found a source of thematic inspiration in medieval history, e.g. The Formal Entrance of Sigismond in Strasbourg in 1414, a fresco ordered for a local high school, The Judgement of Richard Coeur de Lion on a stainedglass window for the History Museum of Haguenau, in northern Alsace. His works reveal an admiration for the Renaissance German masters, such as Albrecht Dürer and Hans Baldung-Grien, with a similar interest in detailed and precise landscapes and portraits. As a mark of this stylistic filiation, one of Schnug's signature paintings

\section{KARGER \\ Fax +4161306 1234 E-Mail karger@karger.ch} www.karger.com
Francois Sellal, MD

CMRR, Département de Neurologie

Hôpitaux Civils de Colmar

FR-68024 Colmar Cedex (France)

Tel. +33 389124 150, E-Mail francois.sellal@ch-colmar.fr 


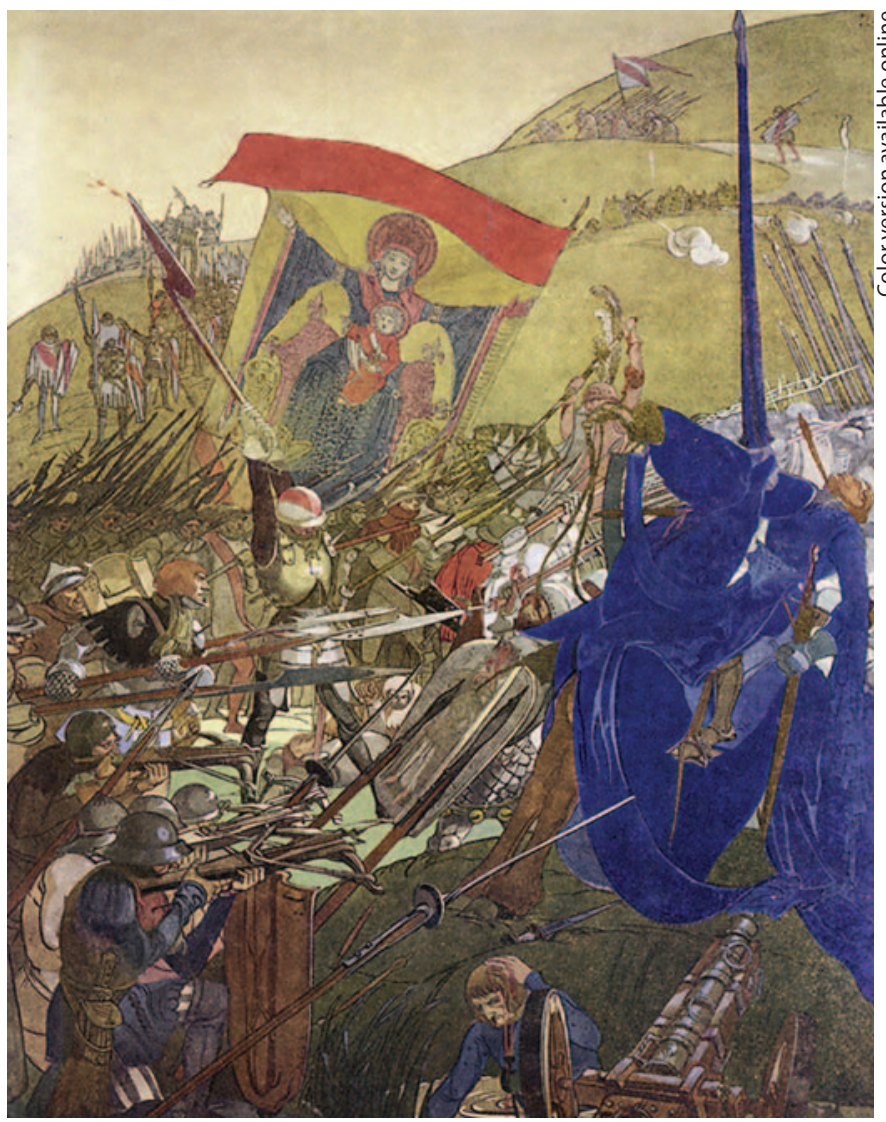

Fig. 1. The Battle of Nancy (1477). Painting by Leo Schnug at the height of his art.

was designed as Dürer's monogram. In his paintings from the very productive 1900-1910 period, he showed a particular gift for painting expressive, colored and animated historical scenes from the Middle Ages and the French Revolution (fig. 1). He acquired international fame, took part in the restoration of the Wartburg castle in Thuringia, Germany, and was appointed by the Emperor William II to decorate several rooms in the newly restored Haut-Koenigsbourg Castle in Alsace. He also proved to be a skillful drawer and engraver, producing many ex libris in which the influence of the art nouveau curved and flowery style appears.

William II decorated him with the Order of the Red Eagle, an order of chivalry in the Kingdom of Prussia, but, once enrolled in the German army in 1914, he was declared unfit for service, because he was described as aggressive, disrespectful and impulsive. His unpredictable behavior can probably be explained by his severe al-
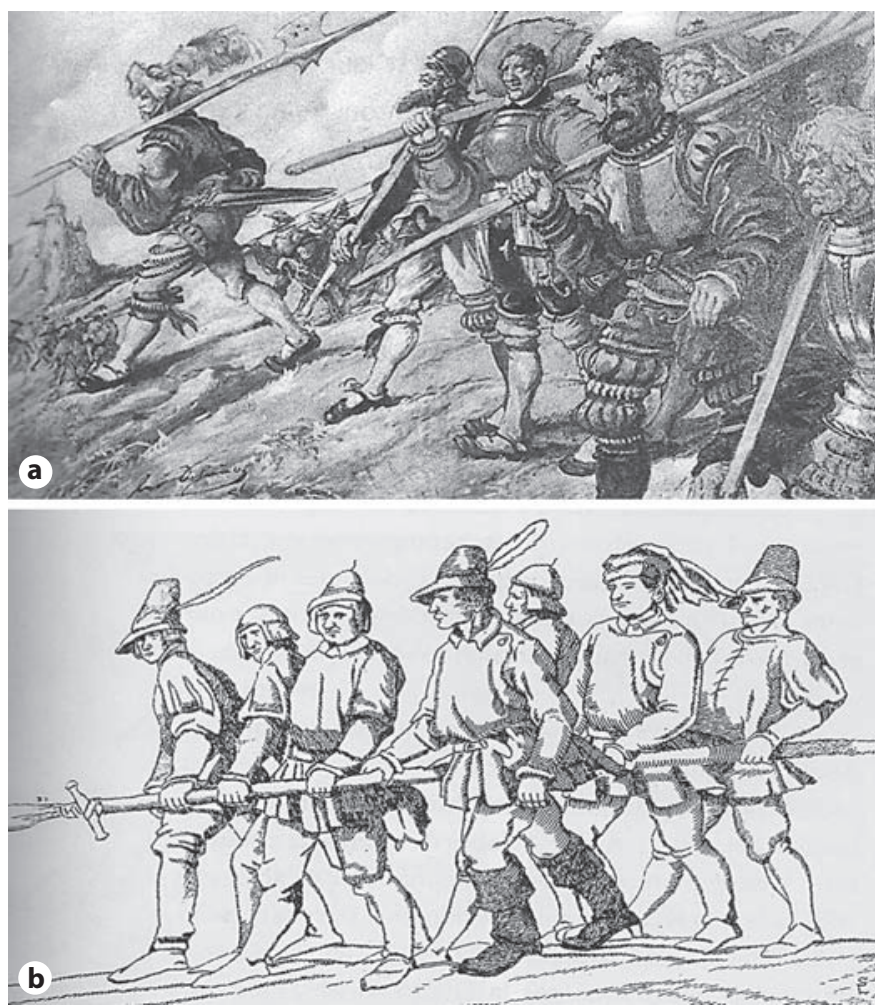

Fig. 2. a A Group of Halberdiers. Early painting by Leo Schnug. b The Seven Lansquenets. Leo Schnug has lost his ability to depict the movement of the lansquenets and draws using short strokes.

coholism, since the painter acknowledged drinking 10 bottles of beer and 2 liters of wine every day [6].

In 1918, he had himself committed to the Stephansfeld mental hospital, near Strasbourg, for 1 year to withdraw from alcohol. Interestingly, during his stay, Schnug's father was unexpectedly hospitalized in the same institution for paranoiac delusions. Unfortunately, Schnug returned to a psychiatric institution in 1920, never to come out again. On admission, he was described as having a cerebellar tremor, limb dysmetria and 'muscle weakness'. He was also disoriented in time and space, anxious, had frequent visual and auditory hallucinations, and developed delusional persecutive beliefs. This mental deterioration had been detected in 1914, but had progressively worsened. Nevertheless, he never stopped painting and drawing, sometimes on a simple piece of paper, the back of a timetable or, on the request of the medical staff, on the asylum's dining room walls. 

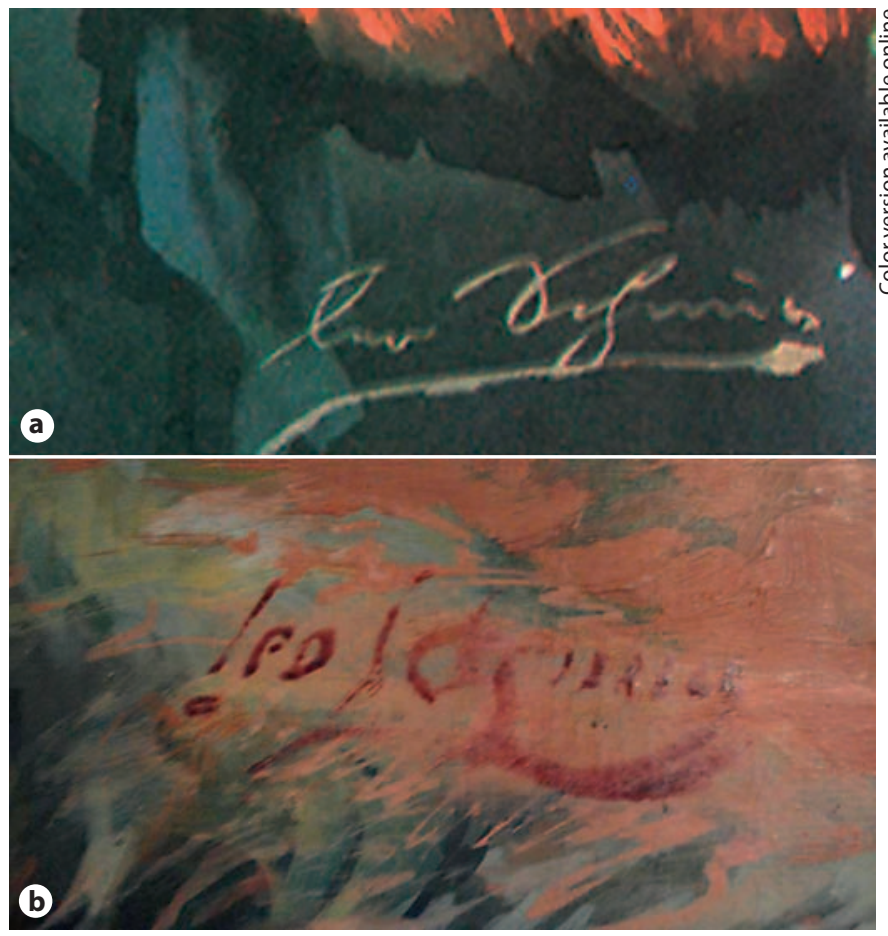

Fig. 3. a A specimen of Leo Schnug's signature before his illness. b A late specimen of Leo Schnug's signature. The brush strokes are less precise.

His production during his period of institutionalization shows two major changes. First, whereas Leo Schnug excelled in suggesting the movement of his characters in his earliest works (fig. 2a), they seem static, rigid and awkward in his latest drawings (fig. 2b). He was no longer able to draw with vigorous, rapid and sure strokes. He instead drew using very short and repetitive strokes, to mask his hand tremor (fig. 2b), with a tendency to press hard on the paper with his pencil, a sign of his dysmetria. The paintbrush strokes were also thickened and less precise, a change which is easy to observe in his evolving signature (fig. 3).

Second, the themes he painted changed dramatically. While Schnug had mainly been inspired by historical themes and loved depicting military costumes with a wealth of details, he turned to the representation of anonymous characters, sometimes lost in a threatening and crushing landscape. In figure 4 , the main character is a

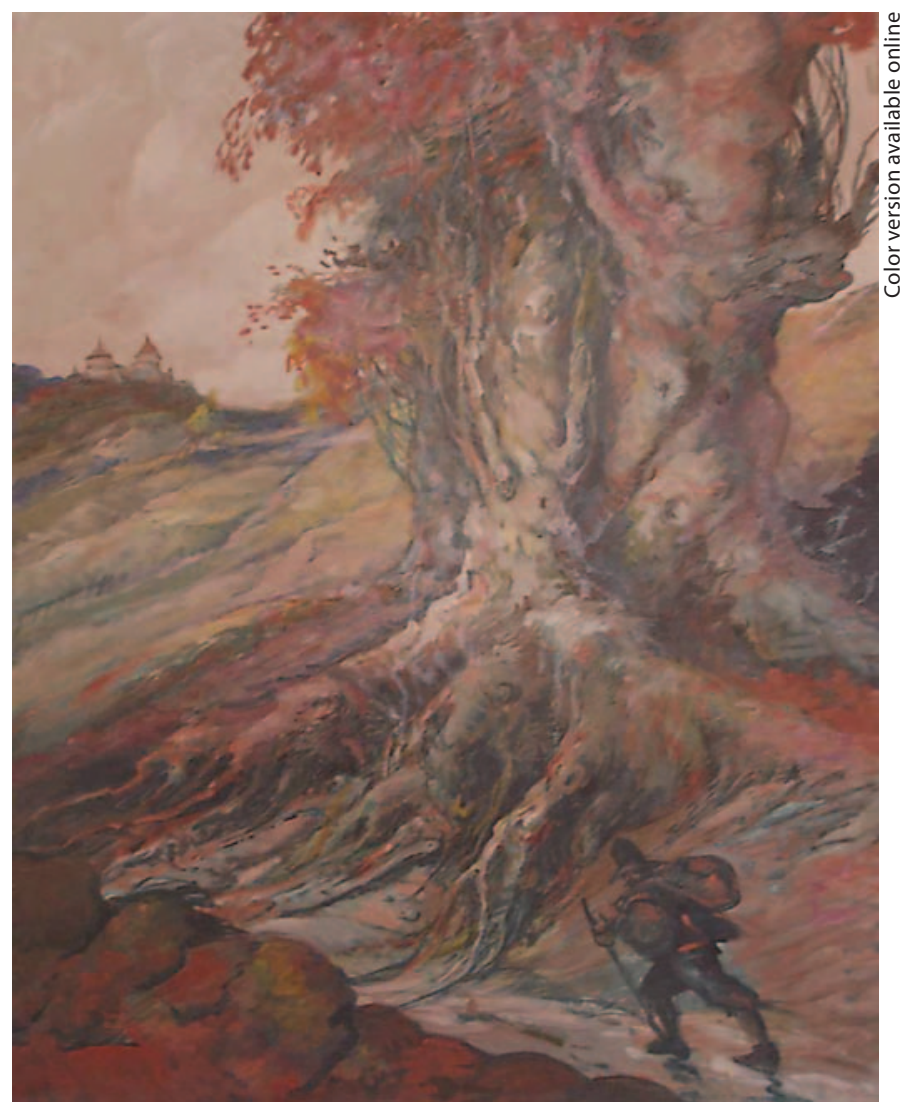

Fig. 4. Unnamed. A man walking to a castle. Late painting by Leo Schnug.

huge tree, with monstrous and tangled roots, dominating a walker who is hurrying to reach a faraway castle at twilight. Some authors have stressed that in these threatening and dark landscapes, it is easy to find hidden human faces [7]. The representation of Schnug's visual hallucinations is more clearly suggested in an ink drawing where he represents himself facing a strange creature, mixing the characteristics of a rat, a cat, a dog and a man (fig. 5). During his second hospitalization, Schnug described 'big beasts' that no longer frightened him [6, 7]. Sometimes, in an attempt to laugh at his own disease, he also represented himself in uncomfortable situations such as vomiting. 


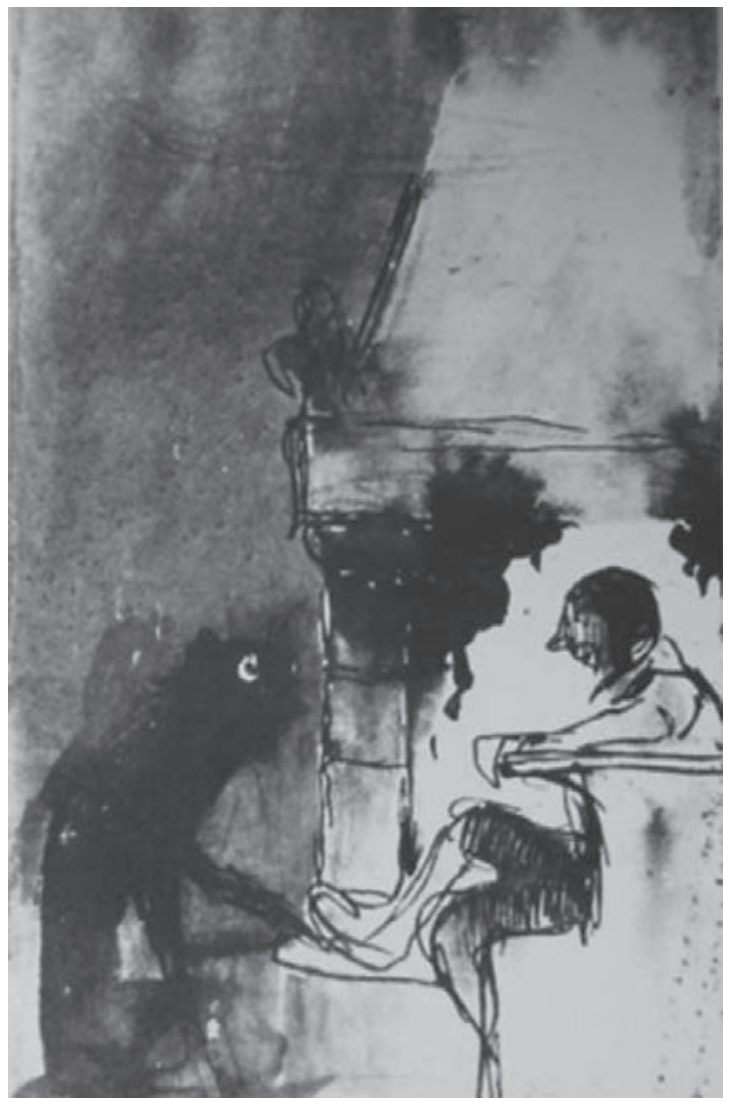

Fig. 5. Unnamed. Drawing of zoopsia from Leo Schnug, at a late stage of his disease.

\section{Discussion}

The emergence of de novo artistic talent has been conceptualized as a paradoxical facilitation [8], which manifests as a disinhibition of brain areas devoted to visuospatial processing, but also as a greater freedom in a patient who becomes less bound by social and academic conventions [1]. For Leo Schnug, the dramatic changes in his output stem from two other mechanisms. First, his cerebellar tremor prompted him to give up drawing with long and rapid strokes. To mask his tremor he had only two solutions, either drawing with short and rapid strokes (fig. 2b) or painting with repetitive, undulating and less precise paintbrush strokes (fig. 3). Second, he suffered from alcoholic dementia, which developed on a borderline personality, with an adaptive disorder. Leo Schnug probably had the same psychic disorder as his father. $\mathrm{He}$ had early megalomaniac ideas of grandeur but, thanks to his artistic creativity, they were initially sublimated in grandiose historical scenes. Later, the occurrence of vi- sual hallucinations, mainly of 'big beasts', his frequent panic attacks with sensations of imminent death, and his loneliness obviously inspired images of a frightening and threatening nature or representations of grotesque characters [7]. Such a representation of a huge, dominating and sometimes crushing nature gives to Schnug, in his last paintings, some filiation with the romantic German painter Caspar David Friedrich, famous for his Tragédie du paysage (the tragedy of landscape).

The influence of hallucinations has been put forward to explain the work of artists who develop Parkinson's disease, like a German artist who painted the faces, bodies or silhouettes she saw on the tree trunks or stones, when taking amantadine [9]. Hallucinations have probably influenced the output of Mervyn Peake, a famous painter, illustrator and poet, who continued to produce tremendously imaginative works despite developing Parkinson's disease or, perhaps, Lewy body dementia [10]. Hallucinations induced by toxic compounds, such as alcohol or opium, were used as a source of inspiration by many artists, such as the French poet Baudelaire, who described the 'paradis artificiels' (artificial paradises), or the psychedelic artists of the Beat Generation. In Schnug's case, as in his family, there was no argument for parkinsonism, and the presence of hallucinations was clearly linked to alcohol withdrawals and alcoholic dementia, probably with a predisposed psychopathic personality. To the best of our knowledge, hallucinations of alcoholic dementia have not been hitherto described as a source of artistic output.

Ben, a French artist, claimed that 'the essence of contemporary art was to innovate, and to do something that the others have not done before'. From this point of view, Leo Schnug's disease led him to unexplored original productions, which were inspired by his psychic disorders and driven by an inextinguishable need to draw and paint. Like some other rare artists [11], he found a personal, expressionistic and easily recognizable style that he probably would not have attained to such a degree had he been in good health.

\section{Acknowledgement}

The author wishes to thank Linda Northrup for her English corrections.

\section{Disclosure Statement}

The author has nothing to disclose. 


\section{References}

-1 Miller BL, Cummings J, Mishkin F, Boone K, Prince F, Ponton M, et al: Emergence of artistic talent in frontotemporal dementia. Neurology 1998;51:978-982.

$\checkmark 2$ Sellal F, Musacchio M: Créativité artistique et démence. Psychol NeuroPsychiatr Vieil 2008;6:57-66.

-3 Maurer K, Prvulovic D: Paintings of an artist with Alzheimer's disease: visuoconstructural deficits during dementia. J Neural Transm 2004;111:325-345.
4 Bäzner H, Hennerici MG: Painting after right-hemisphere stroke-case studies of professional artists; in Bogousslavsly J, Hennerici MG (eds): Neurological Disorders in Famous Artists - part 2. Front Neurol Neurosci. Basel, Karger, 2007, vol 22, pp 1-13.

5 Crutch SJ, Isaacs R, Rossor MN: Some workmen can blame their tools: artistic change in an individual with Alzheimer's disease. Lancet 2001;357:2129-2133.

6 Breitenbach-Wohlfahrt: Léo Schnug ou l'image retrouvée. Strasbourg, Association Mitteleuropa, 1997.
7 Wackenheim A: Léo Schnug. Strasbourg, Willy Fischer, 1971.

$>8$ Kapur N: Paradoxical functional facilitation in brain-behaviour research: a critical review. Brain 1996;119:1775-1790.

$>9$ Ebersbach G: An artist's view of drug-induced hallucinosis. Mov Disord 2003;18: 833-834.

10 Dieguez S: Maux d'artistes. Paris, Belin, 2010 